Jeroen Billiet

\title{
Adolphe Sax's Ultimate Masterpiece. The History, Design and Use of the Cor Sax à six pistons indépendants ${ }^{1}$
}

Introduction The Sax family produced some of the most eccentric, intelligently designed horns in the history of the instrument. Father Charles Sax (I79I-I865) created an omnitonic horn in 1824, and was the first successful manufacturer of valve horns in Belgium beginning in the late I830s. ${ }^{2}$ His son Alphonse Sax (I824-I874) experimented with both conical valve sets ${ }^{3}$ and forward-facing bells.

However, one of the family's most radical horn designs was Adolphe Sax's cor à 6 pistons indépendants.

Adolphe Sax's new approach to the horn - a brief historical overview With his application of the independent valve system to the horn, Sax undoubtedly wanted to provide his own answer to the valve-versus-natural-horn debate of the time. The creation of a horn that would combine the virtues of the natural horn with the practicality and precision of the valve horn was certainly one of Sax's most difficult challenges. On top of that, the possibility of commercial returns was highly uncertain, as horns represented only a small market that was already replete with highly skilled competitors such as Raoux, Courtois and Besson just around the proverbial Parisian corner, plus many other high-level horn manufacturers abroad.

There were thus several reasons why the horn was the last instrument to receive a makeover from the Belgian master, not all of which were technical.

Adolphe Sax had produced other kinds of horns as well: natural horns and "conventional" valve horns, well-engineered and often with beautiful designs, but he never became a mainstream producer of horns. ${ }^{4}$ After successfully applying the system of

1 This research on Sax's independently valved horns is part of the research project "Horn Playing in the Lyrical Style, I850-I950" conducted by the present writer at Antwerp Royal Conservatory-AP institute in 20I4-20I6 and the doctoral research project "Brave Belgians of the Belle Epoque, Ghent University 2015-202I".

2 The production of Charles Sax's successful valve horns continued with Ferdinand Van Cauwelaert père from I847 onwards; see Jeroen Billiet: Poetic Voices. The Horns of the Van Cauwelaert Brass Instrument Workshop in Brussels in the Ghent Royal Conservatory Historical Instrument Collection, in: Larigot Spécial 29 (June 2019), pp. 58-67.

3 The Brussels Museum is home to two interesting instruments by Alphonse; see: Malou Hayne/Ignace De Keyser: Catalogue des instruments Sax au musée instrumental de Bruxelles, Brussels I980, pp. II6f.

4 A fine example of a Sax natural horn is No. E.730 in Musée Instrumental de Paris (produced i844). Valve horns seem to have been produced in greater numbers. In Jean-Georges Kastner's Manuel général de musique militaire (Paris I848, plate xxıv: "Nouveaux Instruments du Système Ad. Sax", Nos. 9 
independent valves to other brass instruments during the I850s, he started working on a horn with independent ascending valves by the second half of the r86os. 5 In I866, Jules Demersseman wrote his Fantaisie pour le Nouveau Cor Sax à 3 Pistons et à Tubes Indépendants. ${ }^{6}$

At the I867 Paris exhibition, Sax presented horns with 3, 4 and 5 independent valves. At the same exhibition he showed his progress with other instruments equipped with this system, as noted in Fétis's favourable - yet not fully convincing - review of Sax's development from 1867 , in which he praised the instruments for their precision of intonation:

"Mr. Sax, having applied to the horn the system of independent valves, an invention by him, has made instruments with 3,4 and 5 valves. The horn with 3 independent valves represents 4 horns: to be precise: the one in the key in which the instrument is made plus the keys of F, E and D. The 4-valve horn represents $\mathrm{D} b$, and the one with 5 valves also produces the key of $\mathrm{C}$. In every one of these keys one can find all the open notes of the horn, and because the tubing is independent, consequently the notes are in tune. The artist always has the right note on every key that is necessary and can immediately produce the right note."

"M. Sax, ayant appliqué au cor le système de pistons ascendants, dont il est l'inventeur, en a fait à trois, à quatre et à cinq pistons. Le cor à trois pistons indépendants représente quatre cors, à savoir: celui du ton de l'instrument et les tons de fa, de mi et de ré. Le cor à quatre pistons représente le ton de ré bémol, et le cor à cinq pistons, le ton d'ut. Dans chacun de ces tons se trouvent toutes les notes ouvertes du cor, parce que les tubes sont indépendants, et conséquemment les notes sont justes. Ayant toujours à sa disposition telle note de l'un de ces tons qui lui est nécessaire, l'artiste la produit immédiatement."7

and Io), Sax's I840s valve horn model is described as "cor à cplindres perfectionné avec tous ses tons". This horn model was copied by the Mahillon company of Brussels for its 499 model from the $1850 \mathrm{os}$ onwards. Several specimens of this horn type survive, such as the one in the Brussels miм No. I981.or6.

5 Even if Sax applied independent valves to trumpets and trombones from the early r850s onwards, the valve system had in fact been used before by the Englishman John Shaw, who patented his "transverse spring slides" in I824; see Reginald Morley-Pegge: The French Horn, London, ${ }^{2}$ I973, Pp.35-52, and Eugenia Mitroulia/Arnold Myers: Adolphe Sax. Visionary or Plagiarist?, in: Historic Brass Society Journal 20 (2008), pp. 93-I4I, here pp. I23-I28. In his review of the I867 Paris exhibition, described in footnote 7, Fétis wrongly attributes the invention of independent valves to Sax. Sax patented his system of independent valves in 1852 (brevet français No. ${ }_{4} 4608$ ), with additional improvements in 1858 (brevet français No.3937I). A French brevet was, however, not proof of invention or of intellectual property, as would be the case with a U.s. patent. Also note that the first known surviving specimen of a brass instrument with independent valves only dates from I864 (ibid., p. I24), whereas Sax presented his six-valve trombone to the public in I862 (described in Le Guide Musical of 20 November 1862).

6 Jules Demersseman: Fantaisie pour le Nouveau Cor Sax à 3 Pistons et à Tubes Indépendants, sur un Motif des Deux Reines, Opéra de Montpou, Paris I866. This edition proves that horns with independent valves were commercially released at around that time. The piece, dedicated to Frédéric Schlotmann, the then principal horn of the Théatre Italien, was published around the time of Demersseman's death.

7 He goes on to cite: "M. Mohr, virtuose sur le cor et professeur au Conservatoire de Paris, enseigne aujourd'hui à ses élèves l'usage de ce nouvel instrument, ce qui promet à la France de bons cornistes 


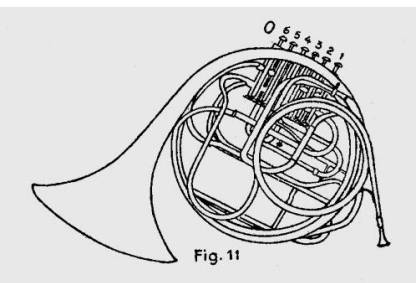

FIgURE I Cor Sax à six pistons indépendants. Illustration from Jules Blangenois: La Fanfare. Traité de l'accord des instruments à pistons et à coulisse, Brussels 1934, front page

FIGURE 2 Fétis's article from Exposition universelle de 1867 à Paris. Rapport du jury international. Instruments de musique, Paris 1867 , p. $5^{8}$. Bibliothèque Nationale de France Musique: Recueils 37 (2). In the margin: "cela n'a pas duré longtemps". Photo by Cyrille Grenot

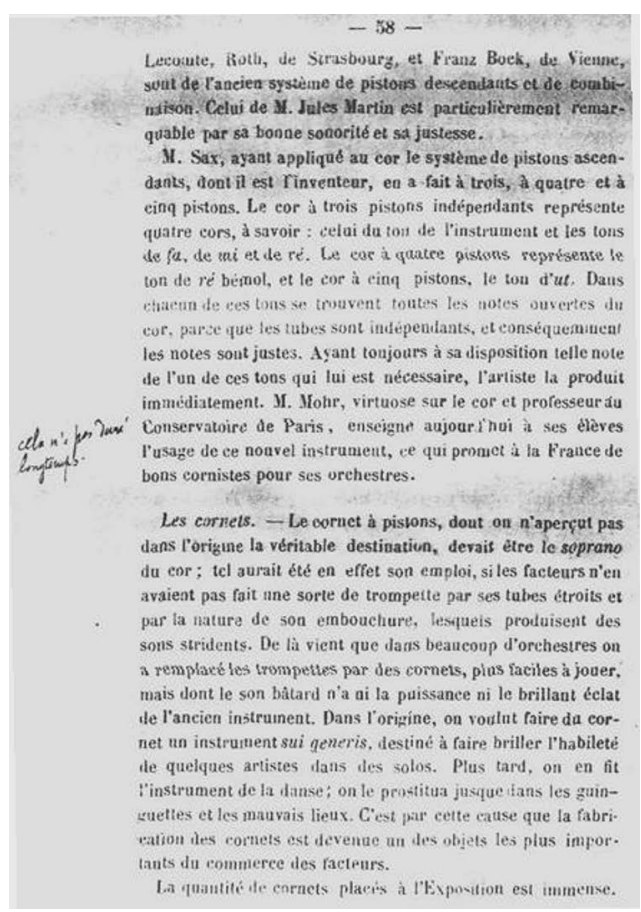

Fétis also stated that these instruments were used in the horn class of Mohr at the Paris Conservatory in this period. However, after a short time, these experiments were abandoned and the institute continued its focus on the natural horn for nearly another three decades.

In I870, further experiments with these instruments were conducted at the Ghent Conservatory in Belgium, amongst others, which acquired three cors à 4 pistons indépendants. ${ }^{8}$ Around that time, Sax expressed his intention to develop an independently valved horn that would only require two different crooks to provide all possible tonalities of the natural horn; this was translated into the invention of the horn with six independent valves some time later. ${ }^{9}$

pour ses orchestres." "Mr. Mohr, horn virtuoso and teacher at the Paris Conservatory, teaches this new instrument today to his pupils, which will provide good horn players for the French orchestras in the future.") Written in the margin in the copy of the BnF report: "cela n'a pas duré longtemps!" ("that did not last for long!") François-Joseph Fétis: Exposition universelle de I867 à Paris. Rapport du jury international. Instruments de musique, Paris I867, p.58.

8 See Jeroen Billiet: Adolphe Sax en de conservatoria van Gent en Brussel. De spraakmakende experimenten met koperblazers met onafhankelijke ventielen (I869-I895), in: Belgisch Tijdschrift voor Muziekwetenschap 70 (2016), pp. I79-189.

9 “Je vais m'occuper d'un cor qui pourra être joueì avec le ton de si b pour les tons aigus et avec le ton de fa pour les autres tons." Letter of Sax to De Burbure, 2I September I869, Ghent Royal Conservatory Library (aBGc), file "Correspondance avant I870". 
When it appeared, the horn with six independent valves was certainly the most advanced horn ever produced. We should not forget that most French orchestras at that time were

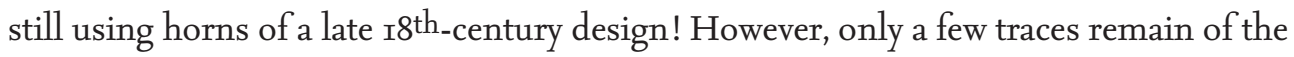
use of horns with independent valves in France. ${ }^{\text {IO }}$

The instrument received an immediate measure of success in Belgium. Louis-Henri Merck (I83I-I900), the leading Brussels horn player and an internationally renowned soloist, was one of the first players to try out the instrument. He actually switched to it, and promoted it among his students and colleagues. In the preface to his Méthode pour le Cor à 6 Pistons Indépendants, written at the suggestion of his director François-Auguste Gevaert (I828-I908), Merck wrote:

"Many players have rejected this instrument because of its weight and supposed complexity of fingerings. I had the same ideas when I saw the horn for the first time, but after having examined it in every detail, I came to admire its perfection. The whole range possesses the greatest clarity, and the intonation is irreproachable; the sound quality recalls perfectly the ancient natural horn that is being abandoned more and more due to the invention of valves and the manner in which contemporary composers write. Contrary to what one would expect due to its massive brass volume, the new horn is of an amazing softness in its complete range, and the entire scale is of a perfectly equal sonority."

"Beaucoup de Cornistes ont dédaigné cet instrument, à cause de son poids et d'une prétendue complication de doigté. Moi-même, j'ai été de leur avis lorsque j'ai vu ce Cor pour la première fois, mais après l'avoir examiné et étudié dans tous les détails, je suis arrivé à en admirer la perfection. Toute l'étendue est de la plus grande pureté et d'une justesse irréprochable; la qualité de son rappelle tout-à-fait l'ancien Cor ordinaire, qui depuis l'invention des pistons, et grace [sic] à la manière d'écrire des compositeurs d'aujourd'hui tombe dans un abandon de plus en plus complet. Loin d'être dur dans le haut, comme on pourrait le croire à cause de son volume de cuivre, le nouveau cor est au contraire d'une douceur étonnante dans toute son étendue et toute l'échelle est d'une égalité de sonorité parfaite."II

Unfortunately, the instrument enjoyed little success with the players of its time. The use of the horn with independent valves went into decline, and only a very limited number of instruments was made. ${ }^{12}$ The Prussian wars and Sax's bankruptcy further impeded its distribution and success, although a few traces of its use after 1876 remain. The Brussels Conservatory even purchased a fourth instrument in 1878 , probably intended to complete the 6-valve horn quartet of the Société des Concerts du Conservatoire. ${ }^{13}$

A 6-valve horn was used for performing stage music at the Paris Opera (bande Sax). This instrument is currently in the collection of the Parisian Museum of Musical Instruments, No. E.967-3.r2.

11 Louis-Henri Merck: Méthode pour le Cor à 6 Pistons indépendants, Brussels [circa 1875], p. 2.

12 See the list of surviving instruments later in this text.

13 The Société des Concerts of the Brussels Conservatory was an orchestra founded by its director F. A. Gevaert, based on the similarly named orchestra in Paris. The institute's teachers featured as soloists, with the best students and graduates at the tutti desks. Gevaert's main intention was the performance of music by "old masters" such as Bach, Handel, Mozart, Beethoven, et cetera. The profits from these 
It remains unclear to what extent Merck actually played the instrument on a daily basis. The instrument with the serial number 37403 in the Brussels MIM shows clear signs of use, but Merck was also associated with Mahillon who made a version of their successful, conventional 499 three-valve horn, called the modèle Merck. ${ }^{\text {I4 }}$ Most students would have played "conventional" horns, as is confirmed by the paltry number of loans listed for the six-valve horns in the register of hire instruments of the Brussels Conservatory:

Cor Sax à 6 Pistons CR5O: 4 loans I873-I893

Cor Sax à 6 Pistons CR51: 4 loans I874-I893

Cor Sax à 6 Pistons CR52: I loans I876-I879

Cor Sax à 6 Pistons CR73: 2 loans I878-I897

Reference: the number of times a Besson natural

horn CR66 was borrowed: 7 times from 1877 to $1883^{15}$

The complex (and completely different) fingerings of the horn with independent valves was surely one of the main issues compromising its popularity.

Moreover, the production and sales cost of these instruments, with their complex structure, made the Sax horns with independent valves far too expensive compared to the mass-produced two-valve or three-valve instruments produced by Sax's competitors. In I87I, a natural horn from Mahillon with all crooks cost 90 francs, while valve horns with a set of crooks were priced at IIO-I25 francs. An invoice from I870 cites a cost of 250 francs for a second-hand (!) horn with 4 independent valves from Sax. At a time when brass wind musicians came mainly from the lower social classes, the choice such purchasers would have made is obvious. ${ }^{\text {I6 }}$

Design, use and playing characteristics In a conventional ascending valve system, valve tubings are often combined to lower the natural harmonics of the instrument. According to Sax, this system compromises heavily on intonation, as the tube length to acquire

concerts were used entirely for the purchase of instruments for the orchestra. Stefaan Verdegem, personal communication, May 2014 .

Mahillon's instruments were often named after a famous soloist or teacher. The linking of a certain name to an instrument type was mainly done for marketing purposes and is not proof that this instrument was recommended to the students of one teacher. The Brussels Conservatory possessed one "model Merck" instrument from 1885.

Brussels Royal Conservatoire, Register of Hire Instruments ARCOI7, unnumbered pages, CR5O-73.

16 See Manufacture générale d'instruments de musique C. Mahillon, in: L'Echo Musical 3/122 (I5. December I87I), p. 4, and Invoice by Adolphe Sax to the Ghent Conservatory, 27 September 1869, in: BGc Financial archive. 
certain notes is often approximate. This is why he was convinced that one way to obtain perfect intonation in a valve brass instrument was to combine seven different instruments into a single instrument, with all the tubing having the exact proportions necessary to produce a pure harmonic series.

On an instrument with independent valves, these are not used in combination. Every valve has its own tube length, calculated to provide the best intonation. This means that the valves are operated one at a time, making the system similar to the slide trombone, with each valve representing one position on the trombone.

The obvious advantage of this system is that the intonation avoids compromising on the tube lengths, as is the case with instruments in which valves (and often crooks) are combined. The "open" position of the instrument represents its longest possible tube length, and every valve pressed systematically shortens the length of the instrument. In theory, this offers many more "perfect" harmonics than the standard descending and ascending 3-valve horn in use in France in that era, ${ }^{\mathrm{I}}$ in which the lengths of the valve tubings were combined. ${ }^{\mathrm{I}}{ }^{8}$ As Merck stated in the preface to his method, the idea behind its invention was to create an instrument that can perfectly reproduce the tonal colour and harmonics of the natural horn.

The main technical problems (and disadvantages) concerning the application of the ascending system to the classical horn are:

- The length of the conventional horn, for which the instrument tubing is considerably longer than, say, the trumpet or the trombone. This necessitates having considerably more valve tubing to produce a pitch difference than when combining the instrument with valves. This increases the weight and production costs. This is a minor issue with a three-valve horn, but the combined valve tubing of the horn with six independent valves is around three metres, each necessitating a tuning slide of commensurate length.

17 In France there were two types of 3-valve horns available: the normal descending horn whose standard configuration was $\mathrm{I}^{\text {st }}$ valve $=-\mathrm{I}$ tone; $2^{\text {nd }}$ valve $=-1 / 2$ tone; $3^{\text {rd }}$ valve $=-I^{1 / 2}$ tone. The second model, the so-called "cor ascendant", designed by Halary in the late I84OS, is a type with descending Ist $^{\text {and }} 2^{\text {nd }}$ valves as described above, and an ascending $3^{\text {rd }}$ valve (+I tone), making the production of high notes more effective and with a brighter sound. This particular valve model would become the French standard by the I88os, and was later adapted by Belgian players, mainly after World War I. The system is sometimes erroneously called "système Belge" because of its popularity among Belgian players up to the i980s.

18 Another common problem with "conventional" horns was that players often neglected the adjustment of the valve slides when changing crooks, as described in Victor-Charles Mahillon: Le Cor. Son histoire, sa théorie, sa construction, Brussels 1907 (Les Instruments de Musique au Musée du Conservatoire royal de Musique de Bruxelles. Instruments à vent, Vol. 2), pp.42-46. 
- Furthermore, at the time Sax was working on the development of the horn with independent valves, horn players were still using the ancient crook system of the natural horn on their valve horns. In addition, Sax's horns were designed to work with crooks in order to be able to reproduce all possible keys of the natural horn. The fewer valves the horn had, the more crooks he needed to use the horn in the way it was intended. As we explain below, Sax did not encourage players to use crooks, but saw them as an option to provide additional possibilities for the players.

- The independent valve system requires dual airflow valves. These were considerably harder to manufacture because an airtight fit becomes extremely important. It is notable that in the six-valve horn, the resistance added by valves 4 to 6 is equal to that of 8 to I2 valves in the conventional Périnet system. The dual airflow system is essential to the independent working of the valves. ${ }^{\text {I9 }}$

It is important to note that applying different crooks meant changing the length of the instrument, which obviously meant a valve tubing adjustment with every crook change. This was a serious disadvantage that became completely impractical with a 5 -valve or 6-valve horn. Adding valves was the obvious solution to the problematic issue of crooking and valve tubing adjustment. Valve design did not become a great deal more complex, but the more valves an instrument has, the greater the resistance encountered by the player. Imagine six valves with dual airflow, a constant airstream that must flow twice through all the valves with serious alternations in the flow. It is clear that this would not easily win players over unless the valve was really well designed. Also, the more valves the instrument has, the heavier the instrument will become, and this mass will undoubtedly influence the tonal colour of the instrument.

The valves on Sax's independent valve horn shorten the instrument to reach higher registers. Combining a 6-valve instrument with a regular F-crook actually turns the horn into seven different natural horns: a horn in $\mathrm{B}$ natural basso, C basso, $\mathrm{C} \#, \mathrm{D}, \mathrm{E}$ b, E and F. Combining with a $\mathrm{B}$ b alto crook results in a horn in E, F, F\#, G, Ab, A and Bb. Despite allowing crooks with his perfectly designed instrument, Sax did not encourage the use of multiple crooks with the independently valved horns. In the "instruction manual" that accompanied the delivery of three cors à 4 pistons indépendants to the Ghent Conservatory in I870, he wrote that "Les cors sont en fa et appelés à jouer tout ce qui est écrit pour d'autres tons, comme cela a lieu pour un autre genre d'instruments (le cor Anglais). Cependant, en attendant qu'on arrive à ce but, il est possible, comme on a pu le remarquer, major issue, likely to make the instrument less homogeneous. In my experience, this is not really the case. 


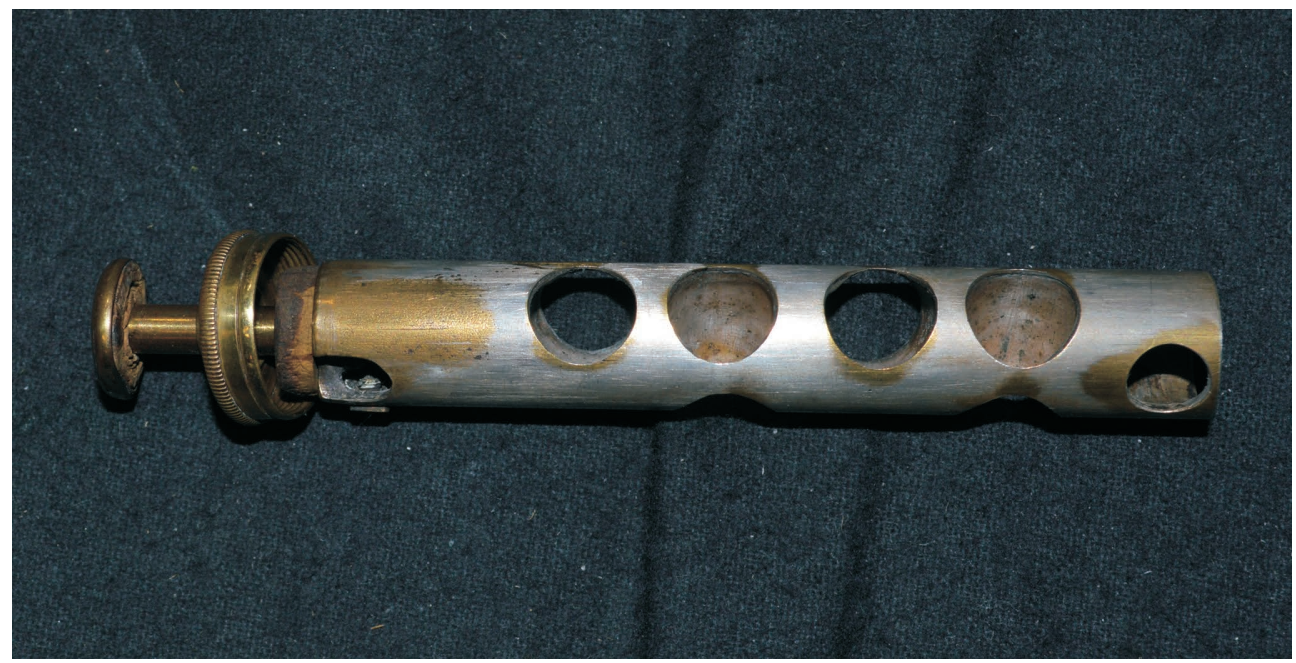

FI GURE 3 Dual airflow valve, cor Sax à 6 pistons, serial number 37403 , Brussels MIM inventory number 3167. Photo: Jeroen Billiet by courtesy of MIM Brussels
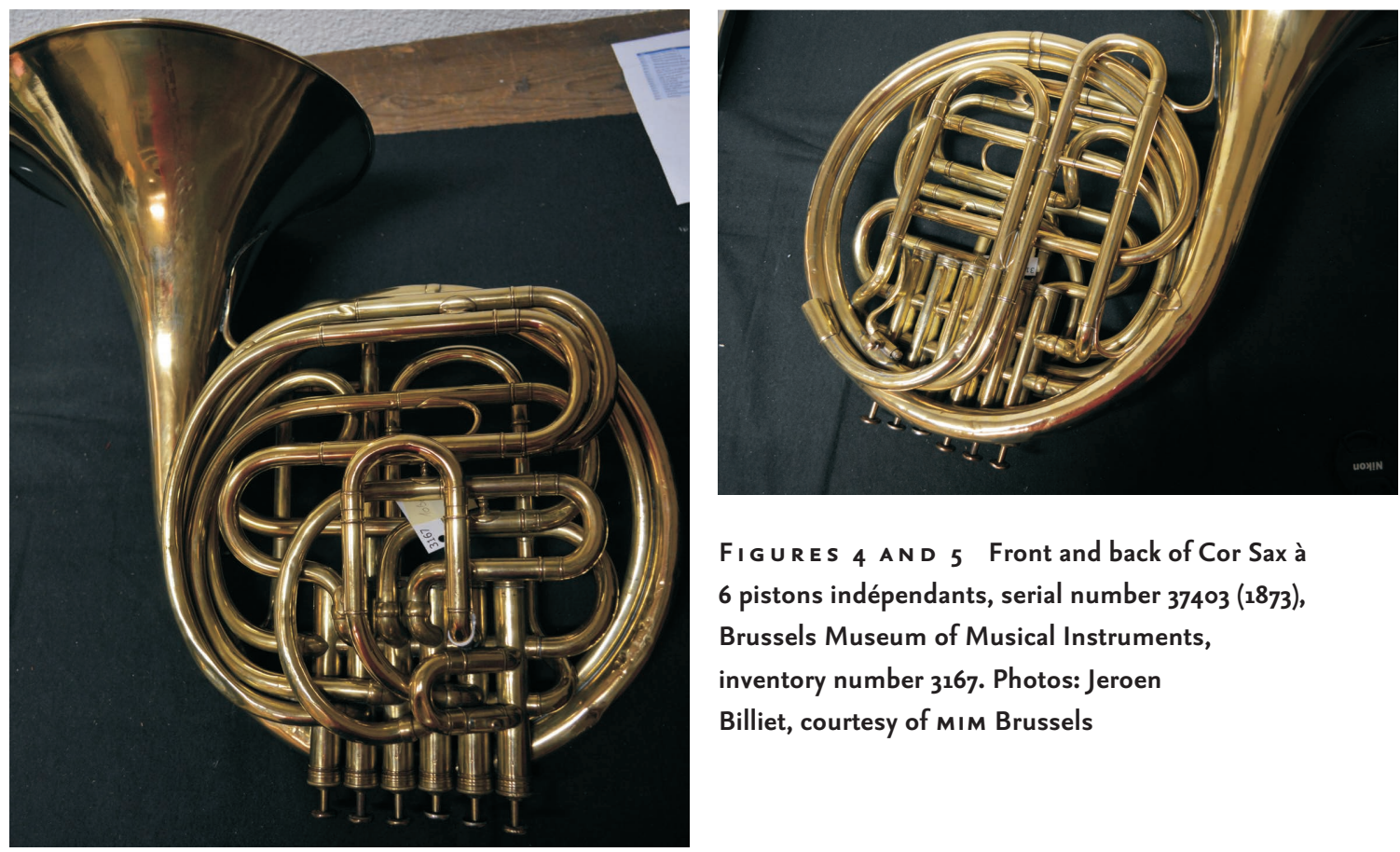

FI GURES 4 AND 5 Front and back of Cor Sax à 6 pistons indépendants, serial number 37403 (1873), Brussels Museum of Musical Instruments, inventory number 3167. Photos: Jeroen Billiet, courtesy of MIM Brussels 
d'utiliser les corps de rechange plus aigus". ${ }^{20}$ In the same letter, Sax also indicated the tube length adjustments this would require.

Commercially, the three-valve version mainly provided a basic model to get people acquainted with the system, but it still needs four different crooks if one wants to reach all possible tonalities of the natural horn. A four-valve version reduces the number of crooks to three. Sax's flagship, a six-valve horn, provided all the tonalities of the old natural horn, using only two short crooks ( $F$ and $\mathrm{B} b$ alto).

I have been able to locate five surviving Sax 6-valve horns, of which three had belonged to the Brussels Conservatory: ${ }^{2 \mathrm{I}}$

One was owned by Henri-Louis Merck, who bought it from the Conservatory in the I89os. It was later donated to the Brussels Museum by Merck's successor Théophile Mahy (I873-I952) and has the serial number 37403; it bears the Brussels Conservatory number CR5O. ${ }^{22}$

A second one was sold on to Henri Dubois and is in the private collection of Van Ryn in Amsterdam (serial number 37562, marked CR5I).

A third instrument is in the private collection of Thierry Bantuelle and Daniel Delhaye in Frameries (Hainaut, Belgium), and has the marking of the dealership of D. Camille in Brussels and the Brussels Conservatory number CR73. According to the Brussels conservatory hire register, it was purchased by the Brussels Conservatory in I878. ${ }^{23}$ It can easily be attributed to Sax, as it is identical to the CR5O and CR5I instruments.

A fourth is in the Paris MIM at Cité de la Musique, and was used for stage music at the Paris Opéra. It is dated 1876 by the museum (serial number 39542).

A fifth specimen, with serial number I2488, is in the St.Petersburg Museum and probably dates from just before $1900 .{ }^{24}$

I conclude from this that the instrument was produced in small numbers over several production years.

I have had the opportunity to play two of the surviving instruments, and have found the sound production remarkably effortless. The so-called extra resistance resulting from the valve configuration is of absolutely no issue.

"The horns are in F and can play everything that is written for other keys, as is the case for other instruments (e.g. the cor anglais). In the meantime, until one reaches this goal, it is possible, as has been noted, to use higher crooks". Letter of Adolphe Sax to the comité de surveillance, Library of the Ghent Conservatory (BgC), bills i87o. The horns used in Brussels have the inscription "CR". Described in Haine/De Keyser: Catalogue des instruments Sax, pp. I67-I69. See Brussels Royal Conservatory Register of Hire Instruments, ARCoI7, "CR73". Attributed to Adolphe-Edouard Sax by Haine/De Keyser: Catalogue des instruments Sax, p. 265. 
In fact, the dual airflow valve system is comparable to the Viennese valve system in which the air flows in a straight line through most of the valve interior. The instrument in the Bantuelle collection is extremely smooth and airtight, the sound bright and compact. The Van Ryn instrument has similar characteristics. The airflow seems tighter, although it is doubtful if the crook on this particular instrument was the original one made by Sax.

The intonation of the configuration tested (F-crook) resembles that of a premium quality natural horn. The sound is very direct, but the sound color seems surprisingly homogenous throughout the range and positions. In contrast to a real natural horn, the sound of $\mathrm{I}^{\text {st }}$ position ${ }^{25}$ (à vide, $\mathrm{F}$ ) is very similar to that of $6^{\text {th }}$ position (C). This is probably due to the mass of the instrument that somewhat flattens out the typical sound of the

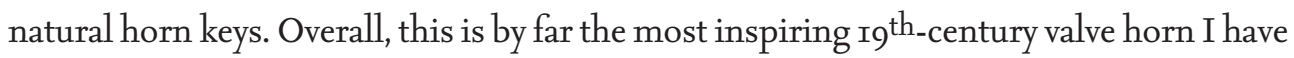
ever played.

Historical sources are not entirely clear about the playing position. In his method, Merck mentioned the possibility of playing stopped notes, necessitating the use of the hand in the bell. The instrument in the Brussels Museum is playable in the "French" playing position, holding the instrument freely in a nearly horizontal position, with the hand only supporting the bell. In this position it is very difficult to operate all of the valves.

Gevaert conversely described playing the instrument with both hands at the valves, forming a "keyboard" for the player. ${ }^{26}$ In two of the instruments inspected, a small metal ring and a hand rest were fitted to the back of the instrument, allowing for the attachment of a strap or belt. As such, the instrument could be played with both hands at the valves. This was probably the most common way of playing the horn with six independent valves, but as with a natural horn, the "normal" playing position could also be used. Mahillon confirmed that the instrument was theoretically "perfect" if only the intonation was considered, but he had serious issues with its weight and the complexity of the valve construction:

\footnotetext{
"It is evident that with regard to intonation, this horn has all one could desire: it is perfect. Unfortunately the instrument is heavy, especially because of the independent valves that require separate tubing of a precise length, while the ordinary system permits one to add length by combining tubings. On the other hand, it is extremely difficult to construct double airflow valves within one instrument. Absolute airtightness of the valves is indispensable if the system is to work well."

“Il est évident qu'au point de vue de la justesse ce système répond à tous les désiderata [sic]; il est parfait. Malheureusement, l'instrument est lourd, précisément à cause de l'indépendance des pistons qui
} 


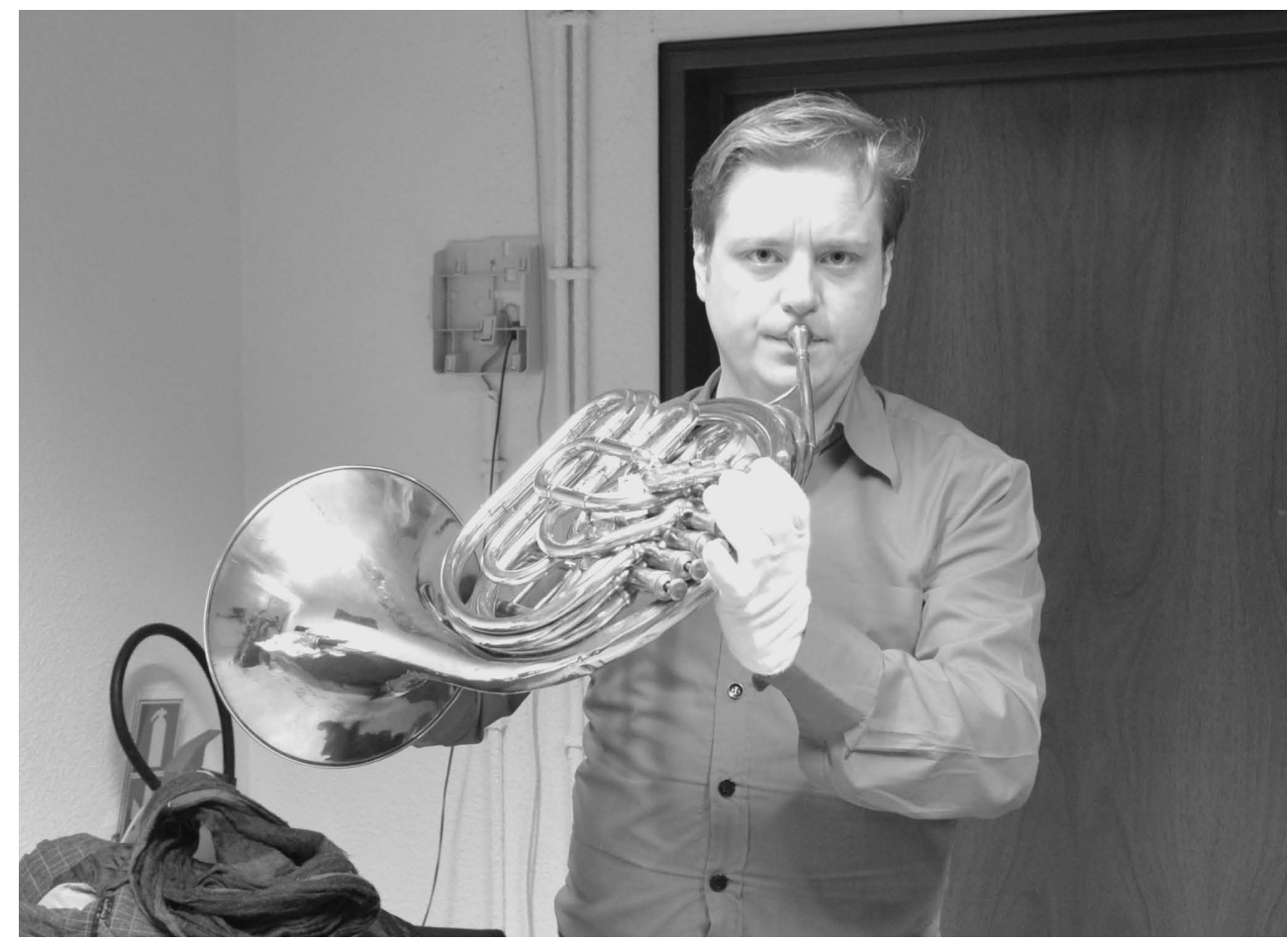

F IGURE 6 Cor à 6 pistons indépendants: French natural horn playing position

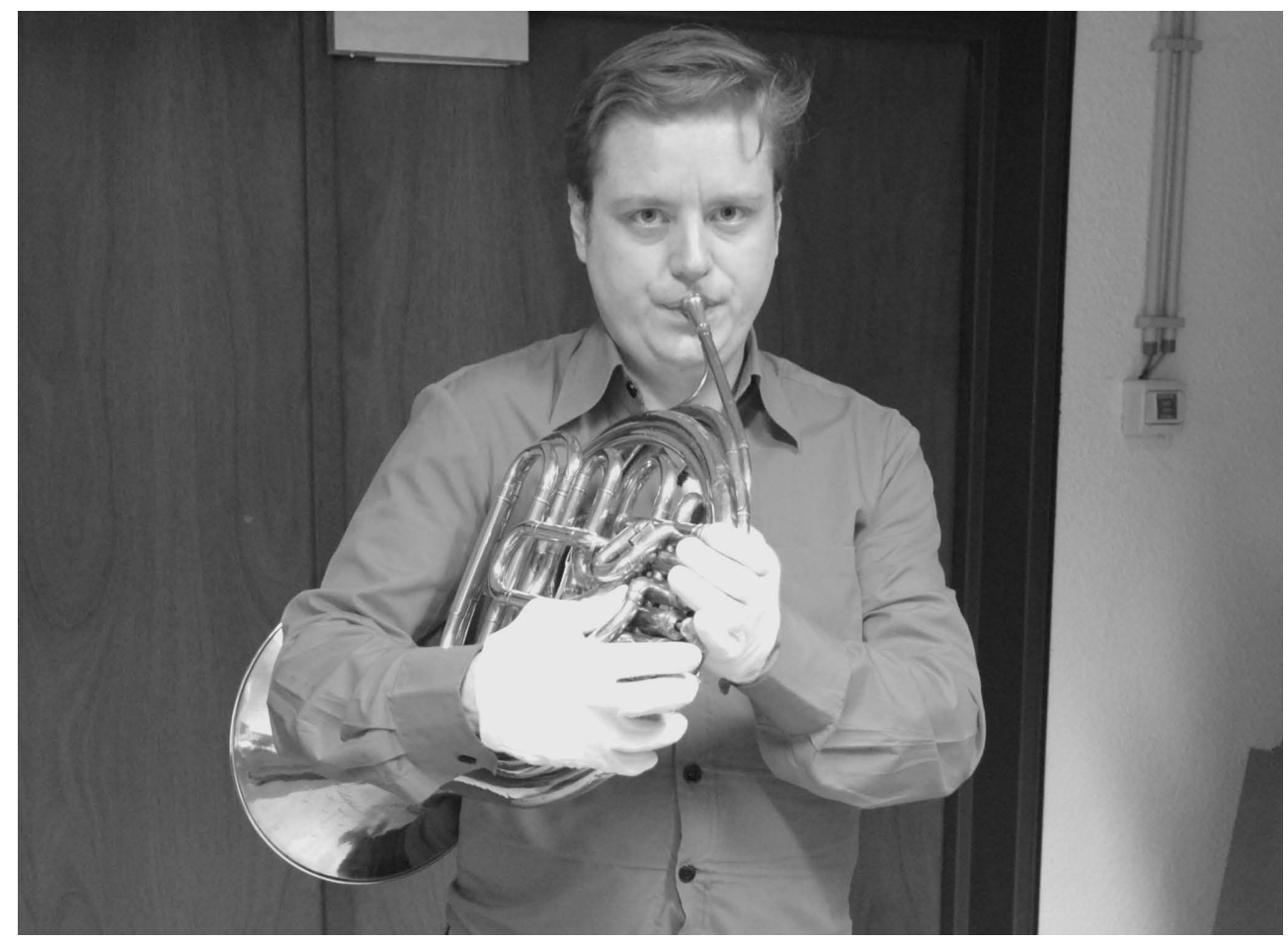

F I G U RE 7 Cor à 6 pistons indépendants: Keyboard playing position as described by Mahillon 
exige pour chacun d'eux des tubes spéciaux d'une longueur déterminée, alors que le système ordinaire permet d'additionner ces longueurs en les combinant; d'autre part, il est extrêmement difficile de construire des pistons à double canal dans un seul corps. Or, l'étanchéité absolue est une condition indispensable du bon fonctionnement de ces organes. ${ }^{.7}$

Conclusions The masterpiece of engineering embodied in the system of independent valves is witness to the true but often misunderstood genius of the great Adolphe Sax. The 6-valve horn, Sax's last creation in his series of instruments with independent valves, was admired by contemporaries from François-Auguste Gevaert to Victor-Charles Mahillon and was used by a leading player such as Louis-Henri Merck.

The cost of the instrument and its complex fingering system were further barriers to its success.

The resistance towards the design was also of an emotional kind. The British musicologist Blandford, who visited Merck in Brussels in I893, commented on this behalf "I had the opportunity of handling a six-valver, which left me with no desire to make its further acquaintance". ${ }^{28}$

The superiority of the system could not win over the conservative horn world of the second half of the $9^{\text {th }}$ century. The horn looked graceful in its details, but was overall far removed from the aesthetic concept of lightness that was popular at the time, so this too will have been detrimental to its chances of achieving popularity.

In some ways, this instrument was too advanced for its time, and with the emergence of the double horn in 1893 , the horn with independent valves became even more irrelevant.

27 Mahillon: Le Cor, pp. 52 f.

28 Letter of Walter Fielding Holloway Blandford to Reginald Morley-Pegge, 26 July 1942 (courtesy of John Humphries). 


\section{Inhalt}

Vorwort 7

Adrian von Steiger "Agilité, homogénéité et beauté". The Saxhorn in the Context of the Opéra and Military Music 9

Eugenia Mitroulia/Arnold Myers The Saxhorn Families I8

Malou Haine Une nouvelle source d'archives pour identifier les marques de fabrique de facteurs d'instruments de musique (I860 à I9I9)

Stewart Carter Kastner, the Distin Family, and the Emergence of the "New" Brasswind Instruments by Adolphe Sax 68

Sabine K. Klaus Wieprecht versus Sax. German Roots of Adolphe Sax's Brasswind Designs 97

Ignace De Keyser The Construction of the Genius in

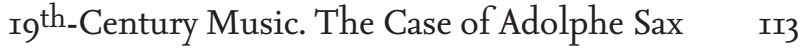

Cyrille Grenot Deux faillites d'Adolphe Sax, I873 et I877. Présentation et documents $\quad$ I46

Reimar Walthert The First Twenty Years of Saxhorn Tutors $\quad 155$

Bruno Kampmann French Makers' Improvements on Brass Instruments in the mid-I th $^{\text {th }}$ Century, Compared with Those by Adolphe Sax $\quad$ I68

Jeroen Billiet Adolphe Sax's Ultimate Masterpiece. The History, Design and Use of the Cor Sax à six pistons indépendants $\quad$ I76

Daniel Allenbach „Une réforme tellement logique« oder »à classer au rang des utopies«? Henri Chaussiers »instruments en Ut« $\quad$ I88

Gregor Widholm Das Wiener Horn - ein Instrument des I9. Jahrhunderts als erste Wahl in Orchestern des 2I. Jahrhunderts 223

Martin Skamletz »... und gar nichts, wodurch sich der eigene schöpferische Geist des Komponisten beurkundete«. Cherubini, Hummel, Konzerte, Opern, Quodlibetes und Trompeten in Wien zu Beginn des I9. Jahrhunderts.

Teil 3 und Schluss: Anton Weidinger und sein Instrument 245

Rainer Egger/Martin Mürner $\quad$ Restaurierungsergebnisse messbar machen $\quad 262$ Namen-, Werk- und Ortsregister 272

Die Autorinnen und Autoren der Beiträge $\quad 283$ 


\section{DAS SAXHORN}

Adolphe Sax' Blechblasinstrumente im Kontext ihrer

Zeit. Romantic Brass Symposium 3 - Herausgegeben von Adrian von Steiger, Daniel Allenbach und Martin Skamletz 


\section{MUSIKFORSCHUNG DER Hochschule der KÜnste Bern Herausgegeben von Martin Skamletz und Thomas Gartmann}

Band 13 
2 Dieses Buch ist in gedruckter Form im April 2020 in erster Auflage in der Edition Argus in Schliengen/Markgräflerland erschienen. Gestaltet und gesetzt wurde es im Verlag aus der Seria und der SeriaSans, die von Martin Majoor im Jahre 2000 gezeichnet wurden. Gedruckt wurde es auf Eos, einem holzfreien, säurefreien, chlorfreien und alterungsbeständigen Werkdruckpapier der Papierfabrik Salzer im niederösterreichischen Sankt Pölten. Das Vorsatzpapier Caribic cherry wurde von Igepa in Hambug geliefert. Rives Tradition, ein Recyclingpapier mit leichter Filznarbung, das für den Bezug des Umschlags verwendet wurde, stellt die Papierfabrik Arjo Wiggins in Issy-les-Moulineaux bei Paris her. Das Kapitalband mit rot-schwarzer Raupe lieferte die Firma Dr. Günther Kast aus Sonthofen im Oberallgäu, die auf technische Gewebe und Spezialfasererzeugnisse spezialisiert ist. Gedruckt und gebunden wurde das Buch von der Firma Bookstation im bayerischen Anzing. Im Internet finden Sie Informationen über das gesamte Verlagsprogramm unter www.editionargus.de, zum Institut Interpretation der Hochschule der Künste Bern unter www.hkb.bfh.ch/interpretation und www.hkb-interpretation.ch. Die Deutsche Nationalbibliothek verzeichnet diese Publikation in der Deutschen Nationalbibliografie; detaillierte bibliografische Daten sind im Internet über www.dnb.de abrufbar. (C) der zeitgleich erschienenen digitalen Version: die Autorinnen und Autoren, 2020. Dieses Werk ist lizenziert unter einer Creative Commons Namensnennung-Nicht kommerziell 4.0 International Lizenz (CC BY-NC 4.o). DOI: https://doi.org/I0.26045/kp64-6I77 ISBN 978-3-93I264-93-2 